Wayside Shrines: Everyday Religion in Urban India

\title{
Enshrining Space: Shrines, Public Space and Hinduization among the Kulung of Nepal
}

\section{Grégoire Schlemmer}

\section{CpenEdition}

\section{Journals}

\section{Electronic version}

URL: http://journals.openedition.org/samaj/4603

DOI: $10.4000 /$ samaj. 4603

ISSN: $1960-6060$

\section{Publisher}

Association pour la recherche sur l'Asie du Sud (ARAS)

Electronic reference

Grégoire Schlemmer, « Enshrining Space: Shrines, Public Space and Hinduization among the Kulung of Nepal », South Asia Multidisciplinary Academic Journal [Online], 18 | 2018, Online since 10 July 2018, connection on 19 April 2019. URL : http://journals.openedition.org/samaj/4603 ; DOI : 10.4000/ samaj.4603

This text was automatically generated on 19 April 2019

\section{$\Theta \Theta \Theta$}

This work is licensed under a Creative Commons Attribution-NonCommercial-NoDerivatives 4.0 International License. 


\title{
Enshrining Space: Shrines, Public space and Hinduization among the Kulung of Nepal
}

\author{
Grégoire Schlemmer
}

1 At first sight, the notion of the wayside shrine may seem an obvious one: to me it spontaneously evokes the myriad of small shrines distributed along the roads all over the Indian subcontinent. They may particularly attract my attention because I'm accustomed to a clear delimitation of religious space in the form of monumental buildings, such as churches. But the difficulty I have in clearly answering the question: "Are there wayside shrines in the Kulung area?"-a valley in Nepal where I have long been conducting ethnographic surveys ${ }^{1}$-leads me to wonder what might be the criteria that characterize a wayside shrine. 
Figure 1

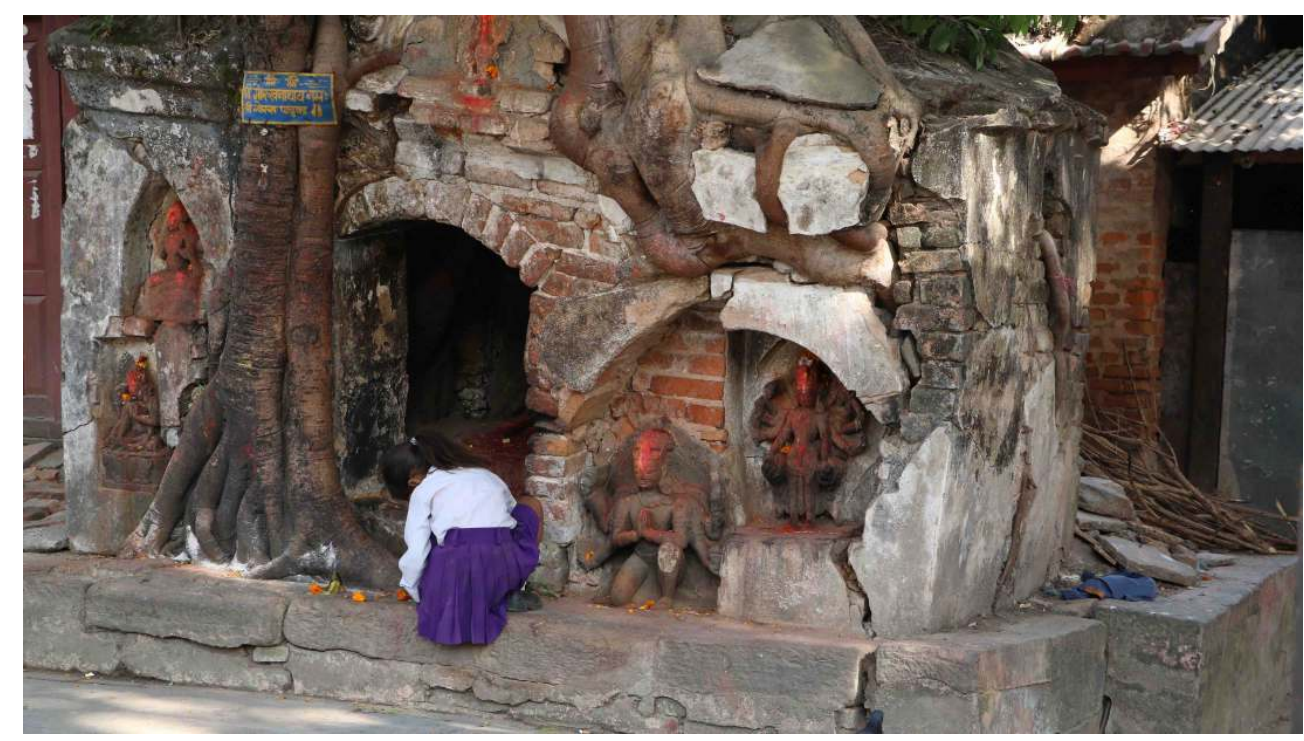

A "wayside shrine"? Small religious edifice built against a bigger temple wall and facing the street, in Kathmandu.

Unless indicated otherwise, all pictures were taken in Bung VDC, Solu-Khumbu district, between 1998 and 2016 by Grégoire Schlemmer.

First, the notion of shrine is rather problematic. As is often the case in religious studies, it is derived from Latin and/or Christian vocabulary (and pervaded by its system), and its meaning fluctuates when it is used to describe elements belonging to other religious contexts. What should be understood by the word "shrine"? Can we group under the same term places that are used as temporary depositories to store offerings for a hungry ghost, and richly adorned permanent places where deities are honored?

I suggest calling all constructions and arrangements made at a particular spot for ritual purposes "material ritual devices" and, within this category, to distinguish a "shrine" from an "altar" at least. Since, originally, the term "shrine" (from the Latin scrinium) referred to a container made for preserving something precious, I propose to take "shrine" to mean: an edifice containing the material representation of a power that is the object of worship. That is to say, the main distinguishing criteria between a shrine and an altar (from the Latin altaria, table for a religious offering) would be the presence of a material representation of a power (e.g. spirits, divinities, etc.). The notion of material representation is broad and is associated in complex ways with the notion of the presence of powers. A representation can be an image, an icon, an idol, a double, a substitute, a container, a manifestation, a seat, etc. (see the illuminating writings of J.-P. Vernant on this topic: 1962, 1983). I will try to more precisely qualify the different types of representation we encounter among the Kulung and the way each representation implies a specific mode of the presence of powers.

3 Now how to define a "wayside" shrine? The term "wayside" appears to be built on a value judgment. If something is said to be "to the side of the way," it is because the way does not lead to it, but elsewhere. A wayside shrine would be a shrine that one sees in passing, on the way to somewhere else, and not a destination. If we put aside this judgment (it seems to be the perspective of the non-pious observer; this point would require at least an ethnographic confirmation from the users of these shrines), and if we suppose that 
this category of wayside shrines has a certain significance, ${ }^{2}$ then what seem to be crucial characteristics of this kind of shrine are its dimensions, namely a relatively modest size, and the fact of it being public in two ways: being directly open on public space, and therefore possibly visited by anyone. If we follow these criteria, wayside shrines can be seen as different from private shrines, which are located inside houses, as well as from shrines whose enclosures separate them from the road, such as most temple shrines. In the latter case, the shrine is also not entirely public: the temple door can be closed and its public can be filtered.

4 We can therefore propose a definition of the wayside shrine as an edifice including material representation, built in a public space and open to all. On the basis of this definition, it is possible to find examples of wayside shrines among the Kulung. Nevertheless these shrines are not specific to them: they belong to religious practices which are common to and transcend several ethnic communities. It should be made clear that the Kulung perpetuate a religious tradition of their own, the ridum, whose rituals are performed in the Kulung language (or in ritual language, sumring, the "language of origins"), while also adopting certain practices derived from what we may call a form of popular Hinduism, whose rituals are performed in the Nepali language. These two sets of rituals, those performed in Kulung and those carried out in Nepali, involve different types of material ritual devices. I will present both types of material ritual device and I will highlight the difference between temporary and permanent ones. The appearance of Nepali shrines is the end result of the borrowing of a ritual technology that can be seen as part of a Hinduization process-but, as we will see, a kind of Hinduization "from below."

5 Trying to more broadly contextualize this process will lead us to discuss some major shifts that have occurred in Kulung society over the last 150 years. We will show that ritual units and land ownership, shrine fixity and cult autonomy, ritual innovation and human migration, goddess apparitions and relations to the state all appear to be interlinked topics. Finally, we will argue that these shifts have led to the advent of the notions of public good and public space, namely the two criteria we have selected to try to grasp what a wayside shrine could be. Again, J.-P. Vernant (1965) demonstrates that for ancient Greece this notion of public space is not universal, but appears only in specific socio-political conditions. Taking his lead, I will try to show that among the Kulung, the appearance of public space came late in their history and precisely in relation to the appearance of new shrines.

\section{Are there Kulung shrines?}

If we stick to the proposed definition of "shrine" as a structure containing the material representation of a power, it is difficult to identify any shrines in the many Kulung rituals (I have enumerated about 80 of them). Indeed, almost none of the Kulung rituals include images, sculptures or even aniconic mediums. There are only some objects (winnowing tray, box, banana leaf, etc.) or installations, such as a small structure made of clothcovered arches. The objects mainly consist of containers, often also used in daily life (plate, calabash, mug, etc.), intended to contain ritual offerings of food. Such a configuration of material objects-a kind of table containing the sacrificial elements-can be considered as an altar. In Kulung, this type of material ritual device is called sum. The term refers to this ensemble of material elements and supports, where and with which 
the operations of offering to and exchange with powers take place: pouring the blood of the chicken, catching the souls thus redeemed, and so on.

But these altars are not present in all rituals. They are absent from those that do not involve communication with a personified power: rituals of casting out anger or a curse, unearthing evil, extracting misfortunes from the body, etc. They are also absent from the simple forms of rituals (sim) addressed to the powers conceived as spirit-diseases that can be more or less personified with a name and a history. These rituals mainly consist of incantations, coupled with a few gestures. The absence of an altar in these rituals is not even compensated by techniques of verbalization or visualization of the power (such as the ones common in tantric Hinduism; Padoux [1990]). The materiality of these rituals is thus limited to only two bodies, namely that of the ritual specialist and that of the sacrificant, with no material elements other than a few leaves which are passed over the body of the sacrificant by the ritual specialist.

Figure 2

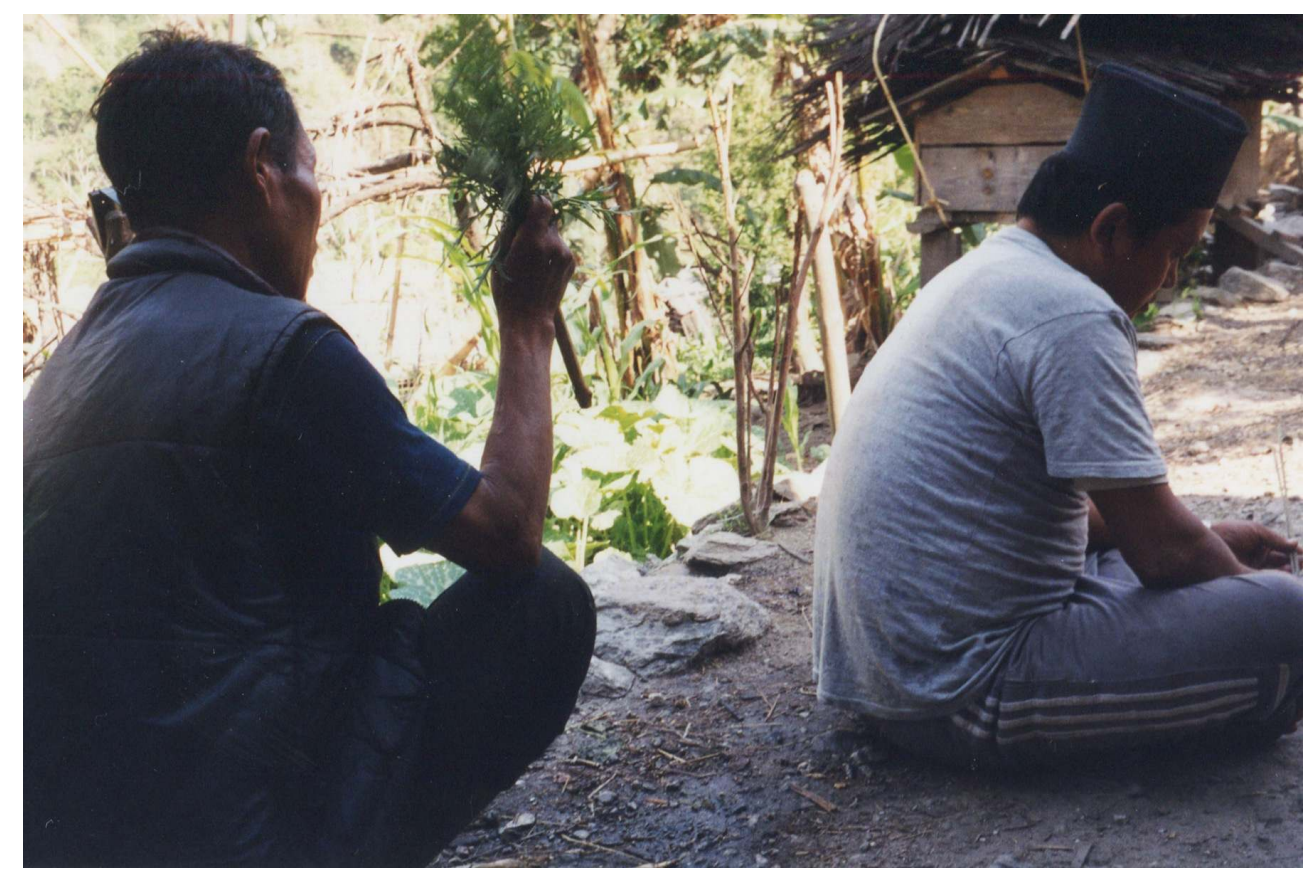

Where is the shrine? Dunima sim, throwing away the spirit-disease Dunima: a ritual without any material element other than a few leaves and two bodies.

This absence of any material representation of power can be linked to the fact that the powers are not honored in any of these rituals. They are conceived of as being the cause of misfortunes. It is thus their intrusive presence in the sacrificant's body that the ritual seeks to expel in exchange for food substitutes. The aim is therefore not to invoke or summon the power-which is indeed already there-but to remove it. Moreover, the power is often returned to its place of origin through a ritual journey. ${ }^{3}$ To put it in another way, these rituals do not aim to incarnate the power, but to "carnate" it, (to use Jean Bazin's words [1986]) by giving it blood and flesh or other food offerings, in order to ultimately disincarnate it out of the sacrificant's body. The place of contact and communication between the ritual specialist and the power is thus the body of the sacrificant itself, which can in a way be seen as the true container of the power. This may be why food is sometimes thrown directly onto it. 
Still powers are not always synonymous with misfortune: in a few cases, the relationship with them is beneficial. In these cases, the rituals are performed at regular intervals of time, as the aim of the ritual is no longer to counter a specific aggression but to give first, in the hopes of receiving later. But in these cases as well, the ritual does not entail a material representation of the power: this is said to be in the body-precisely the shoulders-of the sacrificant (even if sacrificant himself does not necessarily perceive it). The presence of the power within the person's body is seen as permanent, although only activated during rituals. Here we could speak of a "body-shrine." There also seems to be "something" of these powers in the calabashes containing ritual offerings of beer. Indeed, each spirit receives only the beer contained in a particular calabash, specifically reserved for this purpose. Therefore, if the calabash is essentially a container, the fact that it has a permanent association with the power produces a special link between the object and the power itself. It is somehow as if bringing a power and an object recurrently into contact with each other through ritual action entails a kind of contagion of the object itself.

This is even more evident as regards certain material elements in the house subject to ritual action, and sharing major characteristics of a shrine, as they are both demarcated and fixed. These elements are the daplo, the hearth, which receives libations of beer with the aim of removing misfortunes and bringing prosperity; the dampe, a kind of shelf which holds the game meat to be offered to ancestors; and the dicari, a wooden structure used to deposit the jars containing the beer. All these material elements are mobilized during the ritual which is performed bi-annually to honor the ancestors and the "group deity" (kul devatā, nep.), Lucirim or Nagi. But none of these material elements is called sum. Moreover, they are first of all objects of practical use and serving a ritual function is not their main purpose. This is a characteristic that differentiates these elements from the other forms of shrine we shall discuss.

Figure 3

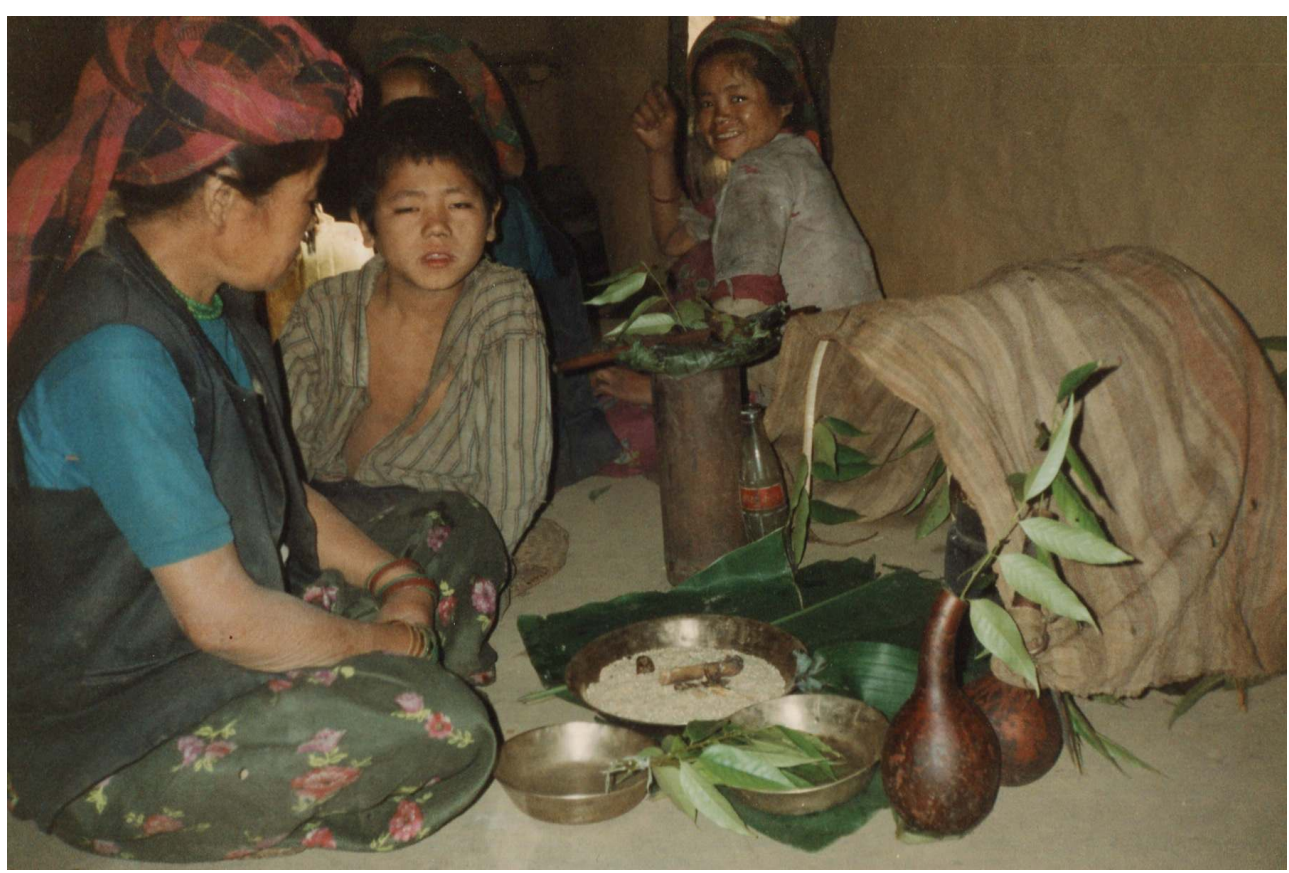

Altar as a kind of table. Performing a ritual addressed to Sitakau, the guardian spirit of the house, in front of a sum, made of foods, receptacles and clothes. 
Perhaps because in the majority of Kulung rituals the relation to the powers happens in the sacrificants' bodies, the places where the rituals are performed lie within the space where these bodies live, namely the houses. While the rituals performed for the powers with which one maintains a permanent relationship are performed inside the house, the house courtyard is for the conducting of rituals for the harmful powers one wishes to reject. The courtyard is open to paths that connect houses, scattered among the fields (even if the settlement is called a "village," tel, the habitat is semi-dispersed). The paths connecting the dwellings are part of the outside. They are therefore potentially dangerous, for they are also open to the circulation of bad influences. It is against this dangerous openness that the ritual struggles, notably by "closing" the space. After the ritual, the elements of these kinds of temporary "wayside" ritual material devices, charged with negative powers, are destroyed or abandoned at the edge of a stream or sometimes along a path. Indeed, a large majority of Kulung material ritual devices are temporary; they must not last.

The fact that all Kulung rituals take place in the space inside and around the house is also consistent with the fact that the Kulung form a society of houses, both in terms of habitat and political organization. Until recently there was no public building or place. The meeting spaces were the courtyards of the houses of important men. Even the paths were not public spaces; they belonged to the owners of adjacent fields.

\section{Tos khom: the only Kulung shrine?}

11 Alongside all of these rituals which are performed by single families, there exists an important Kulung set of rituals which are conducted by larger communities: the tos rituals. These rituals take place at important moments of the agricultural calendar, with the aim of obtaining protection and prosperity, primarily for the fields. They are performed on a fixed stone, theoretically one per village, which is not called sum, but tos khom. Khom means "to cover," and it is one of the components of the term yongkhom "the nest," "the matrix." "This stone is not just a material support, but functions as a catalyst. It could therefore be seen as a sort of material representation of powers, in the sense that the object has a very intimate relationship, is almost identified with a power. It attracts and condenses an otherwise diffuse power: a mixture of a rather impersonal earth-force named Yongkholu and of the ancestors, whose bodies, buried in the fields, feed the land with their flesh. Ancestors have to be called by elders who shout their names in all directions. The ritual action must concentrate these powers together on the stone where the incantations are spoken and offerings-corn and beer-are made. These offerings are then ingested by the participants during the ritual; charged with the benefits of the ritual, they infuse in their bodies "something" of the powers themselves.

Although the area on which this stone is located has a landlord (who plays no specific role in tos rituals), the surface of the stone has no human owner, and it was probably, for a while, the only space in and around the village with such a status. It is under the responsibility of the ritual specialist who performs the rituals and who is designated through a divinatory process carried out among the elders of each founding clan of the village. Indeed, these rituals concern all the members of the founding clans, the legitimate owners of the land. It is therefore a closed ritual: members belonging to Kulung clans historically not present in the village or belonging to other groups and castes are excluded (see below). Echoing the dual nature of the powers which are invoked 
in these rituals-the ancestors and the Earth-participation in this cult is decided by two factors: genealogical and territorial.

Figure 4

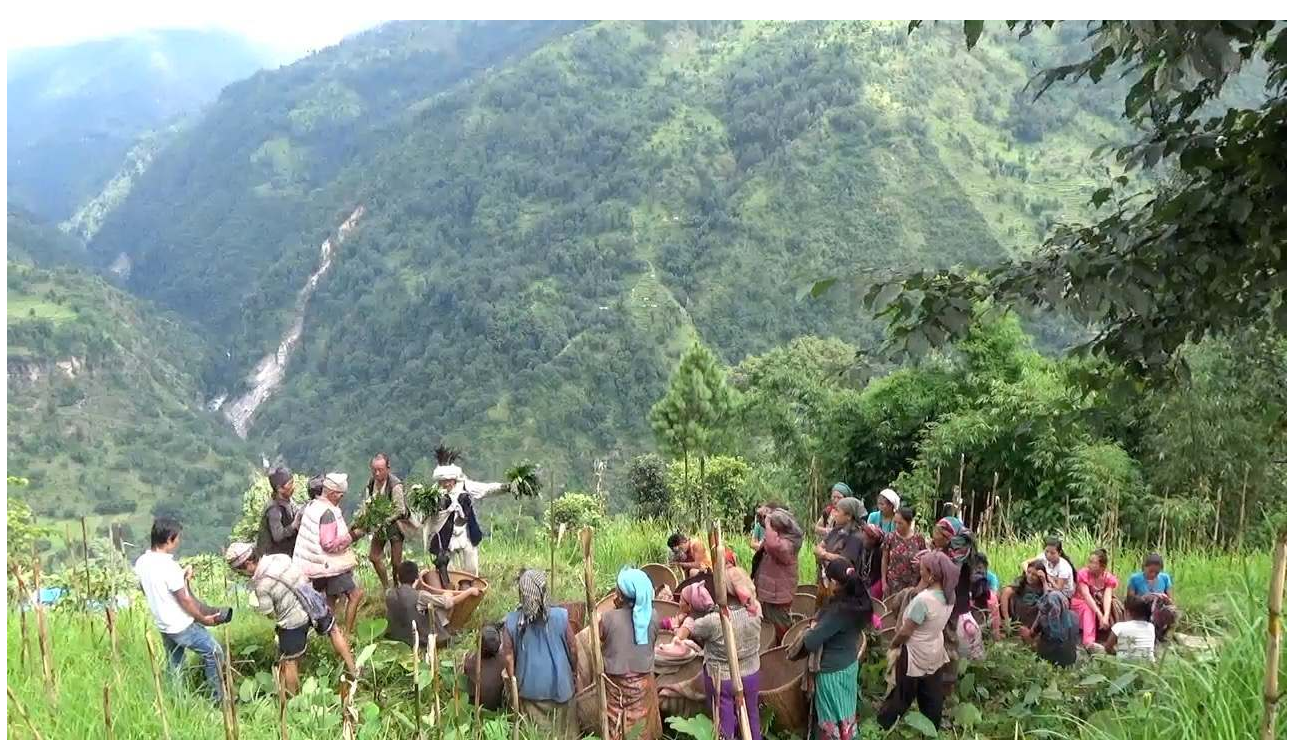

The only permanent Kulung shrine. Performing a collective ritual around the tos stone.

Those able to participate in the tos rituals are in fact those who formerly had kipatiya status, the beneficiaries of kipat land tenure. After the military conquest and integration of what is now eastern Nepal at the end of the eighteenth century, the Nepalese state gave some groups, such as the Kulung, ownership rights over their ancestral land. It did so by implementing a specific land-based regime named kipat, in which the land was the collective and inalienable property of a group (Regmi 1965, 1999). Any stranger to the community wishing to work this land could only be a tenant and had to recognize the authority of the Kulung chiefs (dwāre); for a while this made the Kulung a "dominant caste" (in the sense of Srinivas 1955). Within the community, the property was divided and managed by localized clans.

There is no sign that these tos rituals appeared at the time of this land recognition, as was perhaps the case in Nepal for other earth-related rituals (Krauskopff 1996). But it is very likely these rituals evolved with it (an elder told me that tos started as hunting rituals for calling for an abundance of prey). And there is de facto congruence between the importance of these tos rituals and the status of kipat membership. While it is difficult to reconstruct the pre-kipat land-tenure system, it may be assumed that land ownership rested on a mere principle of recognition of the former land user, as is the case in most societies practicing shifting cultivation, as did the Kulung up until the mid-nineteenth century. This state acknowledgement of the collective possession of kipat had a double effect. First, the land-tenure system shifted from an oral rule conceived on a local scale (addressed to surrounding communities sharing the same land-ownership rules), to a legitimation based on a legal, written, unified law imposed by a State. Secondly, this new tenure system may also have reinforced group identity in relation to the land. Being part of a group became the legal criterion for land access and this was enshrined in the state law. Therefore, the tos shrine became the place of expression of the common good of the community. 


\section{The appearance of Nepali shrines} sacrifice) in front of a material device called thān. This term literally means "place" (the verb thānu means "to locate," "confine to a fixed spot") and is translated as "temple" or "shrine" (Turner 1931:295). For approximately half the rituals, the than consists of a simple branch (generally of artemisia) on which a small piece of cloth is hung. This branch with its cloth is called lingo-dhajo, literally "mast-flag." The mast-flag may be regarded as a marker, indicating a powee, also the other pujar include either a kneaded piece of clay or dung, termed naksā ("drawing," "diagram") or a small stone called sthāpanā ("fix," "establish," "found"), but often in incantatory speech designated by the more prestigious word mūrti ("statue of a god"). Some of the sthāpanā are temporary, others are permanent. Both naksā and sthāpanā act, as does the tos stone, as a catalyst of the power, to which they give shape. There is an implicit idea that the power goes into the object after receiving the sacrifice-this would explain why it cannot be touched after that. These objects can all clearly be called material representations. 


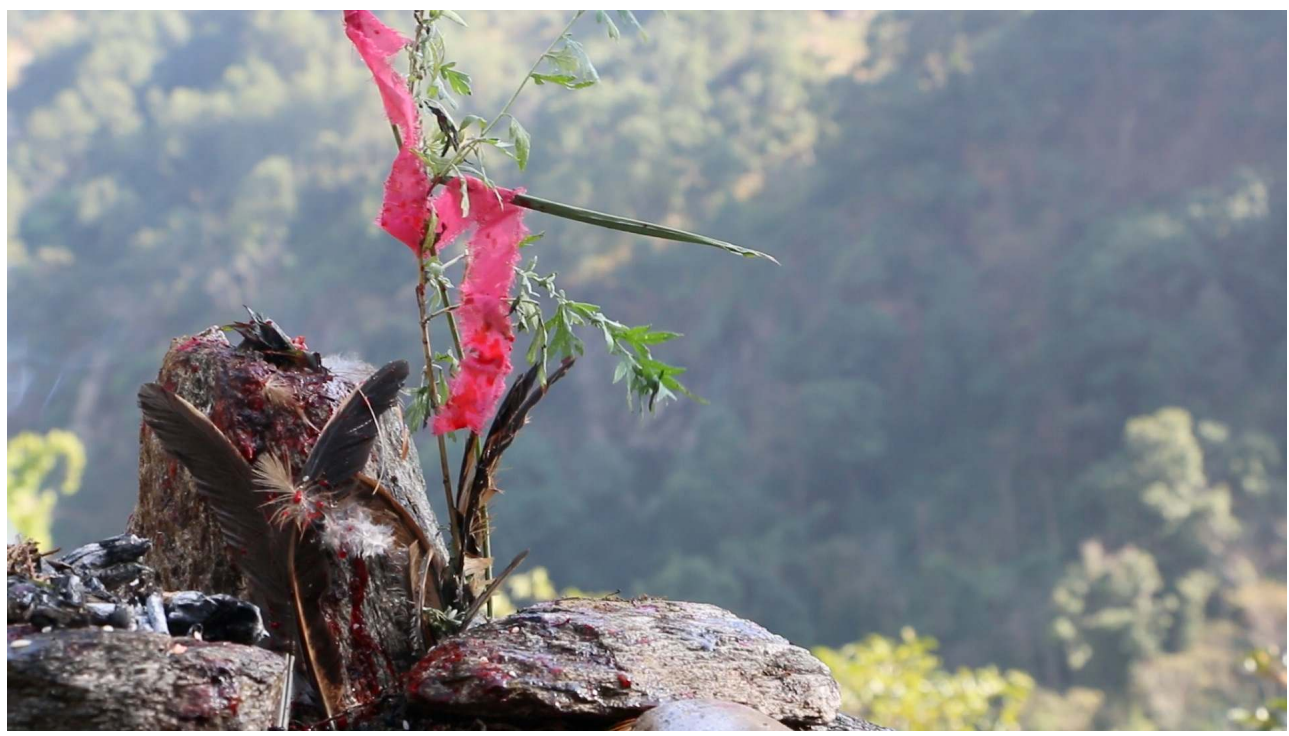

Material representation as ritual innovation? A temporary Nepali shrine (thān) for the river spirit Yowmi. Next to its mast-flag (lingo-dhajo), its stone (sthāpanā) has received chicken's blood and feathers.

These Nepali rituals have been borrowed not by high-caste Kulung and not in order to improve their status, as Srinivas's idea of Sanskritization suggests (1967:6), ${ }^{6}$ but by a Hinduized former Buddhist group of relatively low status. This at least is what Parsuram, a knowledgeable elder, told me: these rituals were initiated by Tamang diviners. Tamang is a group that was classified as "enslavable" by the 1854 Nepali code (Hofer 1979). Some of them settled in the upper part of the valley during the second half of the nineteenth century. This conjectural event is part of a deeper set of changes that affected the region at that time. Before 1850, the only non Kulung in the area were some Sherpa, living in hamlets on the ridge, and a few Blacksmith families, living near Kulung settlements. Later, Chetri families gradually settled in the valley and introduced major agrarian transformations (such as the beginning of field terracing, the introduction of maize and of the plough). Gradually, Magar, Gurung and Tamang also arrived in small numbers. ${ }^{7}$ This led to the emergence of a multi-ethnic environment. The seemingly inherent consequence of this situation is that, with new populations, new diseases arrived and then new rituals for coping with them. Nowadays, the performance of these rituals directed at ousting such kinds of misfortunes is still prescribed to the client during divinatory diagnoses. These rituals manage the dangerous forces of otherness, i.e. powers emanating from the natural environment or coming from neighboring ethnic communities (Schlemmer 2010a). The motivation for adopting these new rituals might have been the need to use the healing techniques of "others" in order to fight new misfortunes coming from "others." This is in line with the pragmatic logic and the intrinsic openness of Kulung practices regarding healing.

17 For whatever reason, a new way of performing rituals for expelling new kinds of misfortunes emerged. To rituals without material representations performed in or close to the house, which often bring misfortunes back to their place of origin through a ritual journey, were added rituals centered on shrines entailing representations and expelling the powers in the open spaces outside the houses. They are most often performed on the banks of one of the streams flowing through the "village" or along paths (so one could in 
a manner regard them as wayside shrines...). Streams and paths work as conduits for these misfortunes. As in the case of Kulung rituals, most of these do not involve permanent shrines. But once the ritual has been carried out, the device is not dismantled; it is simply abandoned and will slowly disintegrate as a result of exposure.

Repeatedly performing rituals in the same place can nevertheless create an association of a power with a site. Thus, the ritual for Sikāri (Hunter), a "forest spirit," requires a larger space than most of the other rituals. This is because, according to the divinatory prescriptions, it can be accompanied by two other shrines, one for Bhureni (old Lady) and one for Eklai Sikāri (Solitary Hunter). It is also necessary to surround these shrines, as well as all the participants in the ritual (a family, the ritual specialist and his assistants), with a thread, in order to prevent their "souls" (law, a kind of energy) from escaping. Because of the danger involved, measured by the fact that Sikāri often makes people sick, this ritual is performed far from the houses. Since they have been used and reused many times for this ritual purpose, the few suitable places to set up such a shrine have become associated with Sikāri. This reminds us of the contagious aspect of powers which was mentioned when Kulung rituals were discussed. To sum up, a Sikāri shrine is not fixed (it is rebuilt on every ritual occasion), but the site on which it is built has become so.

Figure 6

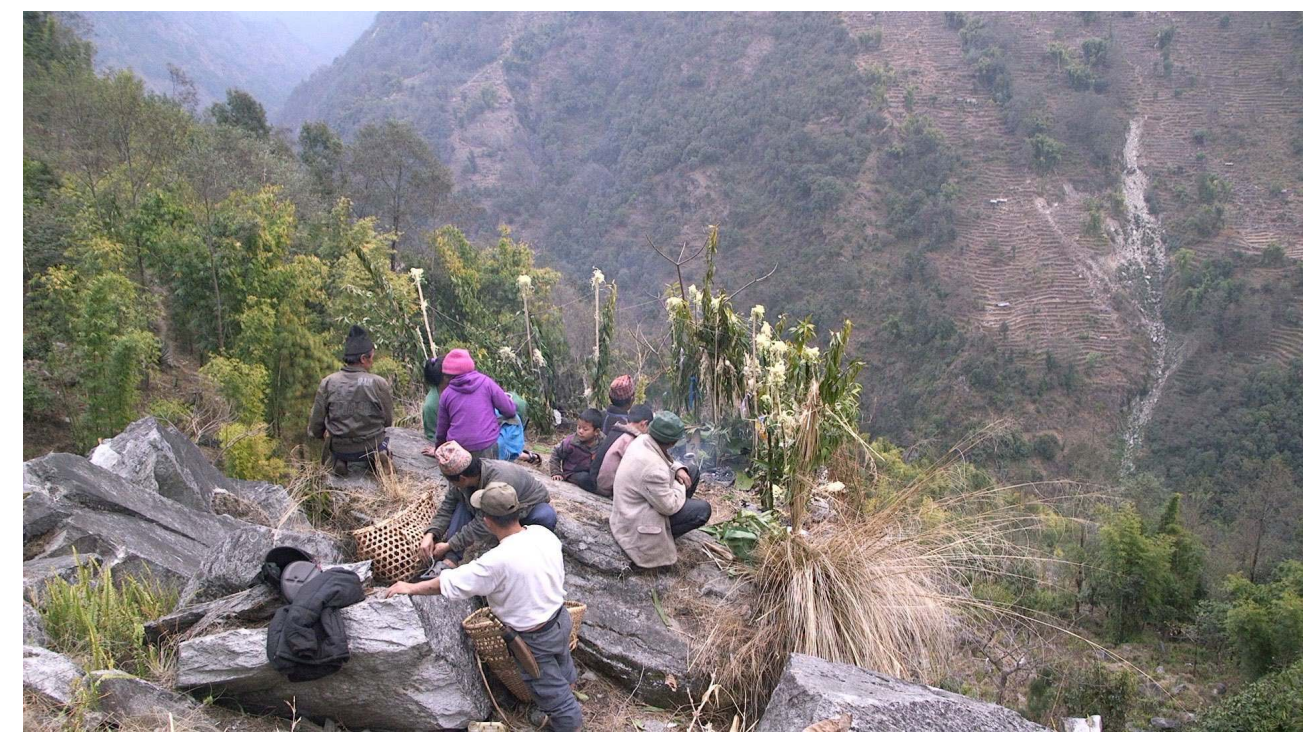

A fixed ritual location attributed out of necessity. The altar of the Hunter-Spirit (Sikāri) and the Old Lady (Bhureni). The structure is rebuilt for each ritual, but in the same spot.

Bhīmasen shrines present a case of a significantly different spatial inscription. Bhïmasen "the Terrible" is the second of the five Pandava sons, heroes of the Mahabharata, but here the name refers above all to a divinity that received the patronage of the king of Dolakha, an old Newar principality which, according to some elders, included the Kulung area in its sphere of influence for some time. The complete form of this ritual is very onerous: it requires the sacrifice of a buffalo, a sheep and poultry, and the presence of all the relatives and allies of the organizer. As a consequence, up to a hundred people may be invited to the feast, in addition to the Damāi musicians who are summoned from afar. Such ostentation is exceptional, and I was surprised that this god with epic roots had no permanent shrine. The history of his worship allows us to understand why. Even if some people say the Kulung were required to bring a goat to the temple in the city of Dolakha 
in ancient times, this ritual was no longer performed at the beginning of the twentieth century. It was in the 1930s that a rich Kulung breeder, who used to go to "Nepal" (i.e., the Kathmandu valley) to sell buffaloes, developed a special friendship (mit) with a Magar from the city of Dolakha, which was on his way. Then he began to sacrifice a buffalo at the temple of Bhimasen, a god known by the merchants to favor trade. As he grew old, he stopped going to Dolakha. But since he was tied to the god, he decided to continue his sacrificial offerings by constructing a shrine on a spot near his village from whence the Dolakha mountain ridge could be seen. Being able to see Dolakha from the location where the ritual takes place has since become the norm when one wants to perform a ritual for Bhimasen. The ritual starts with the building of a "palace" (darbār), which is made of a small slab with a bamboo arch over it, and next to which a mast-flag is raised. At the end of the ritual, the performer brings the god back to Dolakha through incantatory speech, naming the rivers he must cross to reach the city (i.e. a kind of ritual journey). Then he tells the god to stay in his temple. Here the shrine is a kind of temporary antenna connected to a permanent temple. Even if the location of this shrine acting as a relay is not fixed, its "temple referent" is.

Figure 7

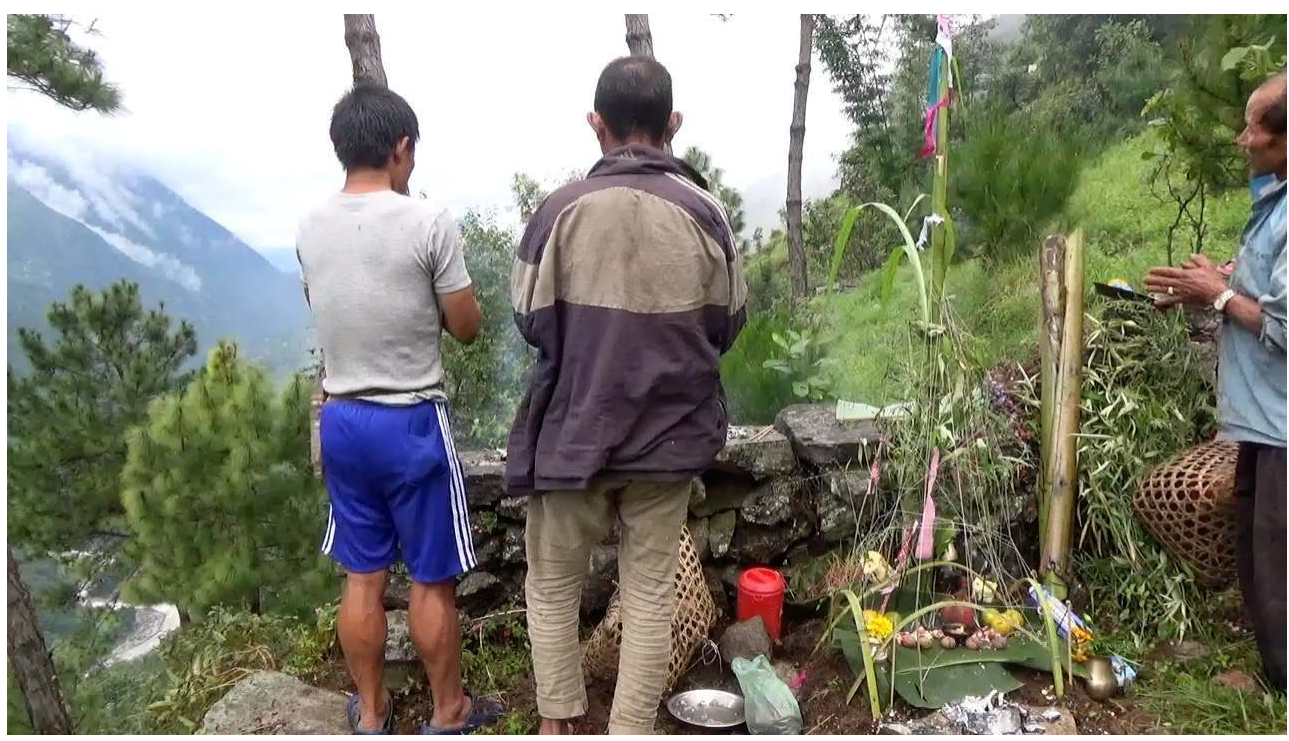

Looking toward a permanent shrine. Sacrificant and ritual performer close to Bhīmasen "palace" ( darbār, on the right) and addressing Bhïmasen looking toward his real palace, near Dolakha.

Aside from ambiguous situations such as Sikāri and Bhīmasen, there are also clearly fixed and permanent shrines, some of which can been considered as wayside, and some of which are not: they are that of Āitabāre, that of the nāg and that of Devī/Mahādev-each possessing their own peculiarities, which I will examine below.

\section{The permanent Nepali shrines}

19 Āitabāre, "the Sunday ones," is perhaps the oldest Nepali ritual performed in the area. It is addressed to a spirit named Āitabāre, who "agglomerate" the spirit of three dead persons: a girl, her maternal uncle and a cowherd boy. No one remembers their history, except for the following details: they belonged to the Sunuwar group (Tibeto-Burmanspeaking populations inhabiting land to the west of the Kulung area); the uncle was a 
hunters and diviner; these three people died on a Sunday in the forest, at the foot of the cilāune (Schima wallichii) tree that is now associated with this ritual. As Āitabāre started to make people sick, people had to begin to feed it through rituals. According to an elder, villagers used to sacrifice cows before this practice was banned by the Nepalese State. Āitabāre now modestly receives a cock and a chicken. The power was formerly worshiped at the foot of a tree of the abovementioned species located in a grove, and by all the inhabitants of a neighborhood (this is still the case in some villages). However, over the past 40 years, the ritual has gradually become a private one, performed at the family level. Altars, marked with a small upright stone, are built on the property of the sacrificant, but still near its associated tree. In addition to the presence of a permanent shrine, this ritual brings in another novelty: it is performed by people grouped together on a spatial basis, namely neighborhoods.

Figure 8

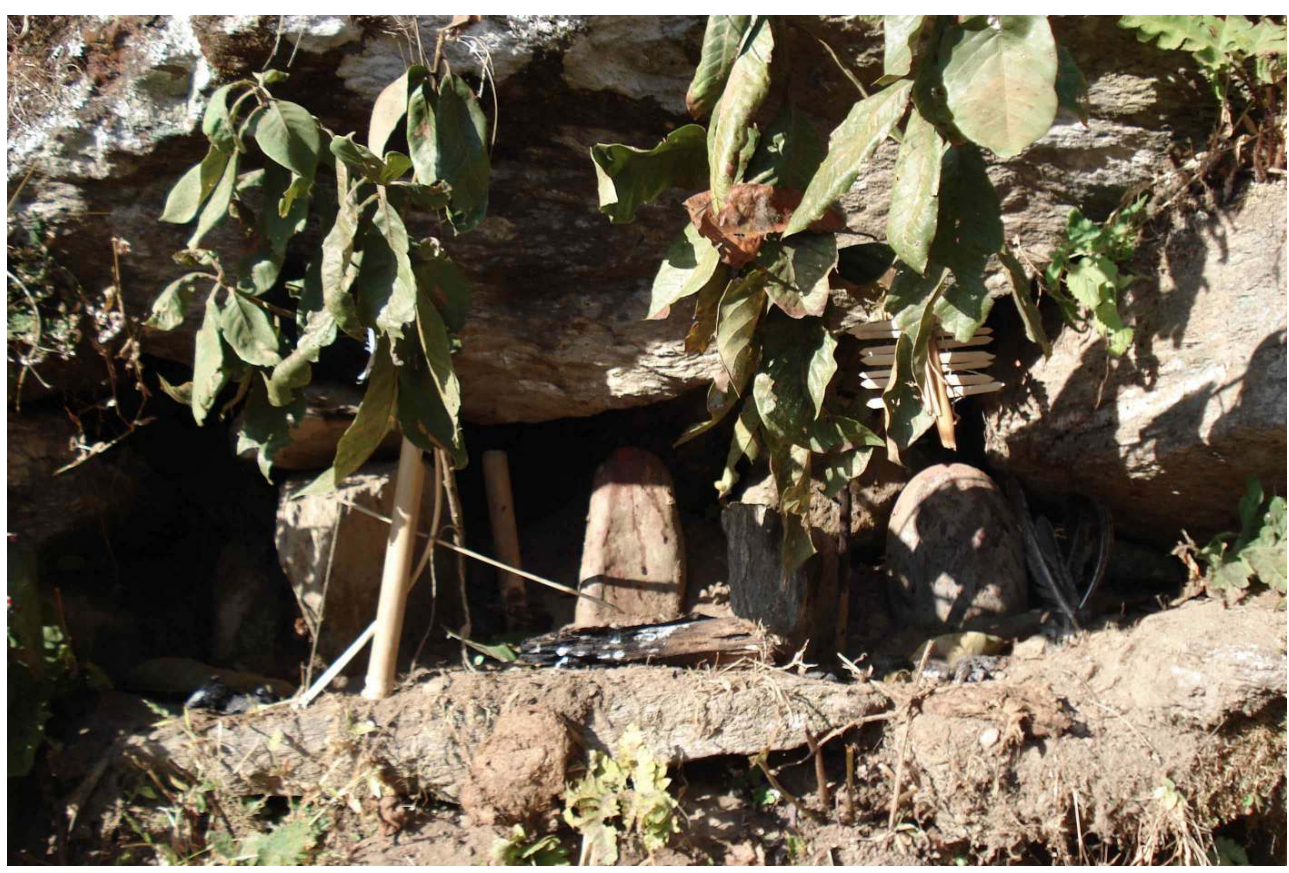

Small, but permanent. A shrine to "the ones of Sunday" (Āitabāre) nestled in the wall of a terraced field We see three stones, three mast-flags, burned-wood for incense and a bow and arrow.

Other rituals are performed by a neighborhood, such as the nāg ritual, which is addressed to the chthonian powers ( $n \bar{a} g$ ) inhabiting the subsoil, and which manifest themselves in the form of snakes. If the importance of Aitabāre is on the wane, the reverse is true for the $n \bar{a} g$ ritual, which is more and more pervasive. Nāg manifest themselves in the diviner's body during divinatory sessions, especially sessions performed after landslides, attributed to $n \bar{a} g$. The diviner must then build a shrine for the nāg by erecting a small stone, in the fields or by the wayside. Here again, one may regard this as a wayside shrine. If divination reveals that the $n \bar{a} g$ has struck several families, all of these unfortunates will have to accomplish the ritual together. If divination reveals that the nagg wants to be installed in a specific already existing shrine, a stone will be added to the designated shrine, such that some of them contain up to 25 stones. As in the case of Aitabāre, all of the people who share the same nāg shrine perform the ritual together, and this can only take place during the full moons of nāg-pacamī (July/August) and śrī-pacamī (January/ 
February). On those days, people who have not been victims of misfortunes brought on by a $n \bar{g} g$ can join these groups, equipped with milk, some rice and coins, in order to formulate a request (for good health, prosperity, etc.). Even if in minimal form, we see here a type of religious practice that was foreign to the Kulung tradition: devotion. By devotion I mean honoring a power without reference to any previous manifestation ${ }^{8}$; in other words, a free act of worship, even if one hopes, of course, to get some benefit in exchange for the investment.

This shift from affliction towards devotion is also well illustrated by the Devī/Mahādev case. Here, these terms are to be taken in their generic sense of "goddess(es)" (devi) and "great-god(s)" (mahā-dev). They are used as general names for powers who may also bear specific names. When manifest, these powers are worshiped in the form of a stone in a permanent shrine. The oldest are non-human powers that manifested themselves ( swayambhu) in specific places (lakes, peaks, caves, etc.) through particular events: the appearance of a tiger, bleeding stones, and so on (see below). In the 1970s, another kind of Devi-Mahādev appeared, produced by the spirits of people who died before puberty or marriage: either girls (called Devī) or boys (called Mahādev). They began to manifest themselves by taking possession of a diviner in order to express their grievances and forewarn of their forthcoming manifestation in the form of a stone, through which their parents should worship them. A ritual is then organized, during which the power takes possession of the diviner again. The power sends him to seek the stone in question, and informs the diviner where to place it, often in a shrine already containing other DeviMahādev.

21 The link between the stone and Devi-Mahādev is different from cases such as that of Āitabāre, for which any stone will do. In the case of Āitabāre the stone is in fact an offering and not a manifestation. Conversely, in the case of the Devi-Mahādev, the stone has a kind of indexical link with the represented object, in C. S. Pierce's sense: it has a relation of contiguity, i.e. is produced by it, such as a footprint; or it is a part of it, such as the bones of a saint (a signification linked with the original meaning of shrine: a box for relics). The spirit of the dead person is thought to be, in some ways, in the stone. It is said, moreover, that when the diviner picks up this stone for the first time, it is hot. The stone of one famous Mahādev (the oldest in the village of Bung, dating from the end of the nineteenth century), has hands and a mouth: these features are purportedly not produced by humans but the work of the power itself. Here we have a new kind of shrine: one that is both a representation of the power and a (kind of) presence of this same power. 


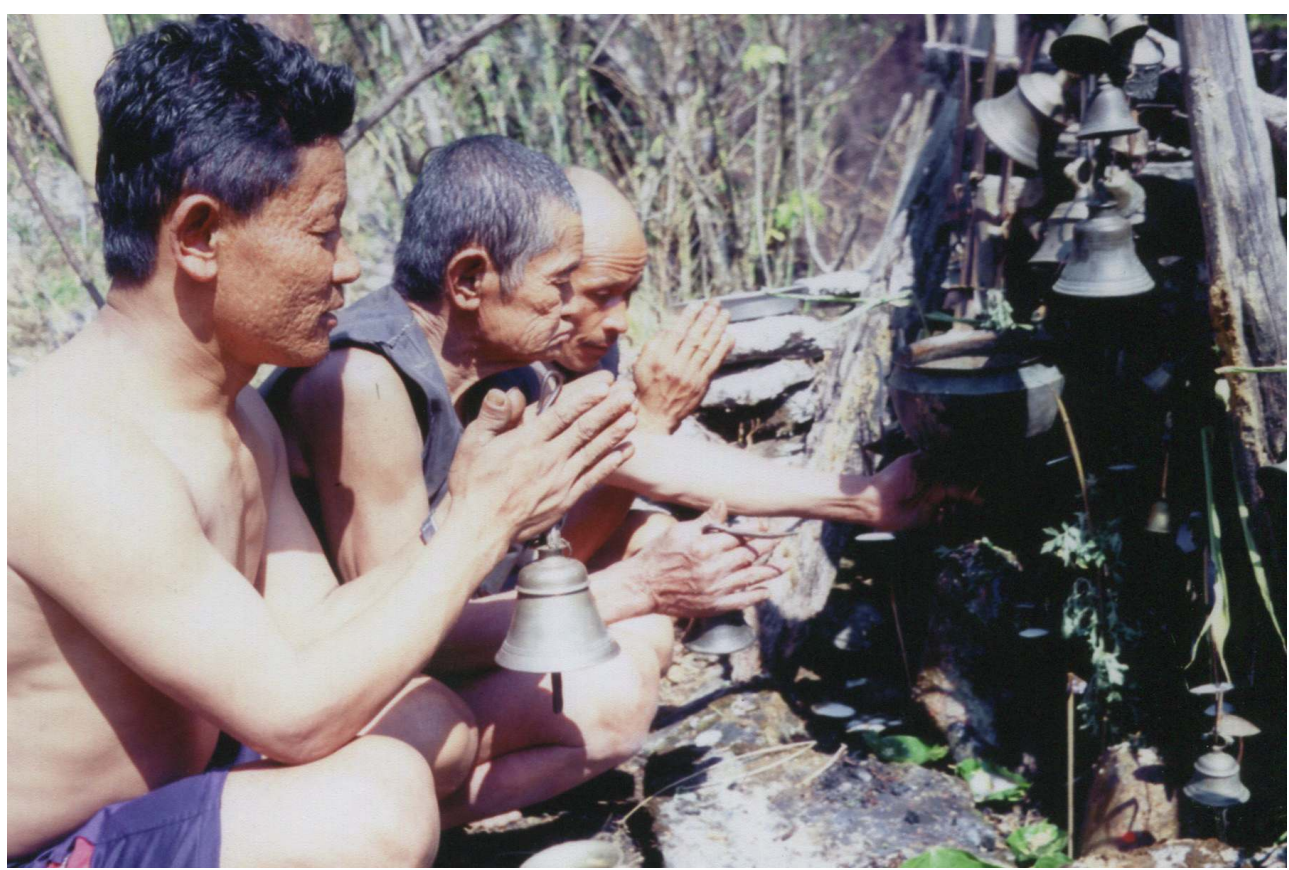

The emerging of a quasi-temple shrine. A permanent Mahādev altar, with tridents and belts given as an offering.

Devī-Mahādev are emerging more and more frequently (there are about 15 new Devī or Mahādev shrines per year in the large village of Bung), and these shrines are becoming increasingly significant. ${ }^{9}$ All of the families of the village end up having a more or less close relative who becomes Devī or Mahādev. The consequence is that these shrines have become collective places. During rituals, the faithful do not only honor their own relative, but all of the Devī-Mahādev present in the same shrine. Up until a few years ago, anyone could go there at any time to make an offering. More recently, the community has established fixed dates for these rituals to be performed collectively, under the direction of a ceremonial leader, called pujāri, who is chosen from among knowledgeable elders. These shrines are the only ones, within this area, that are sometimes called mandir, "temple."10 In the village of Bung, a fundraising event was recently organized to transform the shrine of the oldest Mahādev into a "real" temple, namely a building with an enclosure and a roof. It will be the second one of the valley. Up until now, only the tos stone of Chemsi village has a temple-like roof, which was constructed during the nineties. 


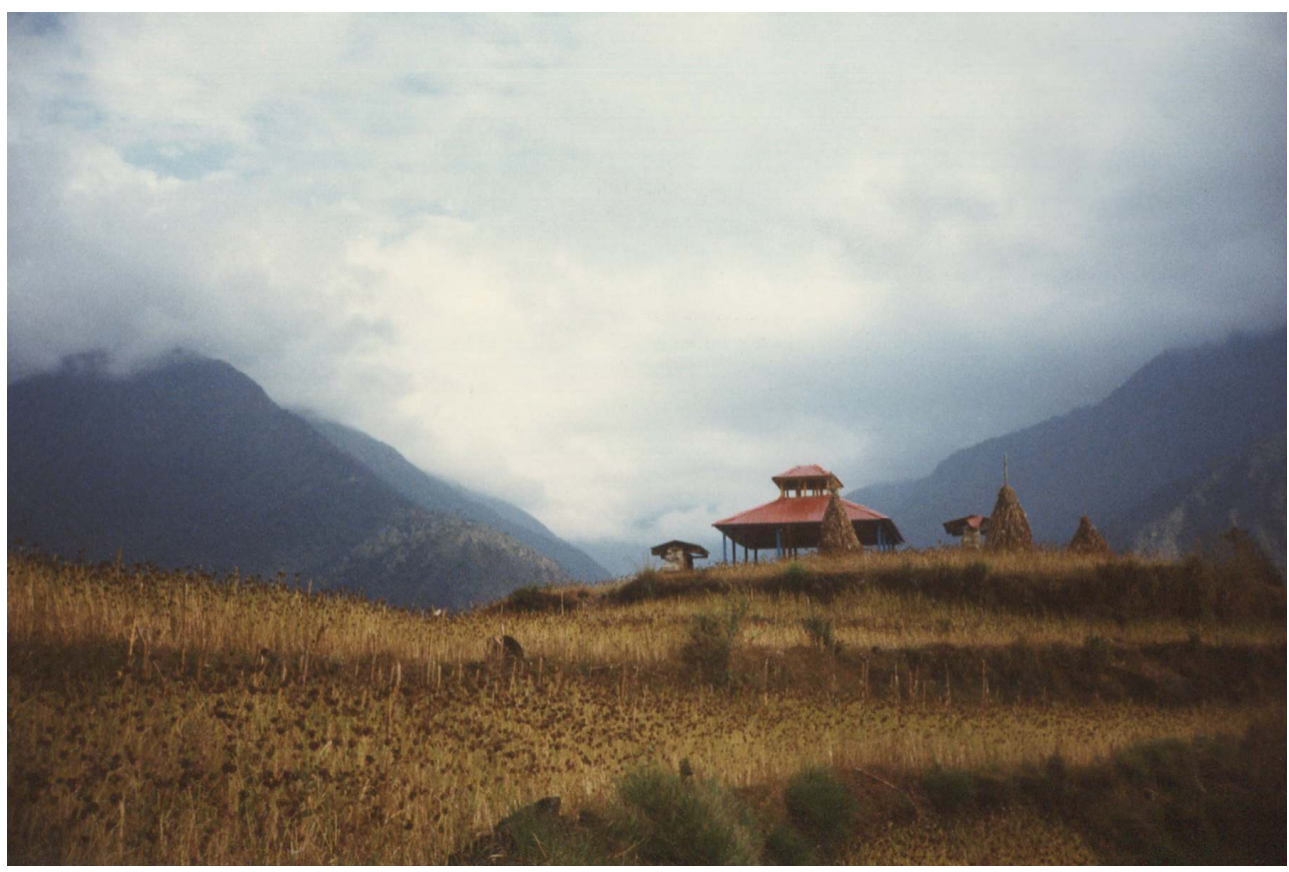

Moving toward the appearance of a temple? A temple-like roof constructed over the tos stone.

\section{State control and public space}

Devī-Mahādev and tos rituals, the two main collective rituals performed not only to counter a specific misfortune but also for general wellbeing, show both similarities and differences. Tos rituals involve the community of landowners, descendants of the community's founders, united by a genealogical link with the honored power. Since most of the Devi-Mahādev are the spirits of dead children, there is also a hint of a genealogical link between the performers of the ritual and the powers addressed. But as we have seen, this genealogical link does not seem to be essential: first of all, the kinship relations with powers only apply to some of those involved; moreover, there are some Devī-Mahādev that are self-generated; additionally, the person setting out to perform the ritual honors all the powers residing in the same shrine without distinction; finally and most importantly, any member of the village, even a non Kulung, can participate in this ritual. ${ }^{11}$ Here, the link between the powers and those who perform the ritual is, first of all, a spatial one. In other words, Devī-Mahādev rituals do not express the ritual performers' anchorage to their territory via the link to the ancestors, as the tos rituals do; rather they express their belonging and connection to a group sharing the same residential space, namely the village community.

Here again it is possible to read this development in light of the concomitant historical changes. Let us recall that the first rituals in Nepali developed a century after the incorporation through military conquest of the Kulung valley into the Hindu kingdom of Nepal and some decades after the advent of the Rānā dynasty (1846-1951). The Rānā governed with an iron fist, relying on the high castes, guarantors of Hindu orthodoxy, and through them, they extended their political administrative control over the country. Among other things, they gradually eliminated kipat (among the Kulung, on irrigated land 
first, in 1907, then on unirrigated land in 1942). Since then, the inalienable collective ownership of the land has switched from clan-based tenure to individual ownership. Chetri were then able to buy the lands that up to this time were occupied through rents (especially the irrigable areas in the south of the valley, as well as some pastureland). This was made easier because many Kulung had contracted loans with them. Simultaneously with the emergence of a multi-ethnic society, there was a progressive commodification of the economy, and especially of land, as ownership was increasingly individualized and privatized. ${ }^{12}$

This state-driven movement toward the commodification of the land thus involved the gradual emergence of the notion of legally-defined private space. But the same process also involved the creation of public space, a change which also affects rituals. This is at least suggested by the following facts told to me by Bakhat Dhan about one of the most important Devi in the valley:

At first, the government decreed a "queen's wood" (rāni ban), saying that this wood belonged to the queen. Afterwards, a tiger appeared there. It started to eat the cattle, which could no longer be grazed. As everyone was wondering what was happening, a diviner was called in. He summoned a meeting and revealed that there was an angry devī. Then the people said, "Even if it's in the queen's wood, we'll install the devī." A shrine was built to the goddess (devi thān), and the place was declared religious land [guthi, lands given to a temple or other religious institution]. It was in the days of my great-grandfather.

Figure 11

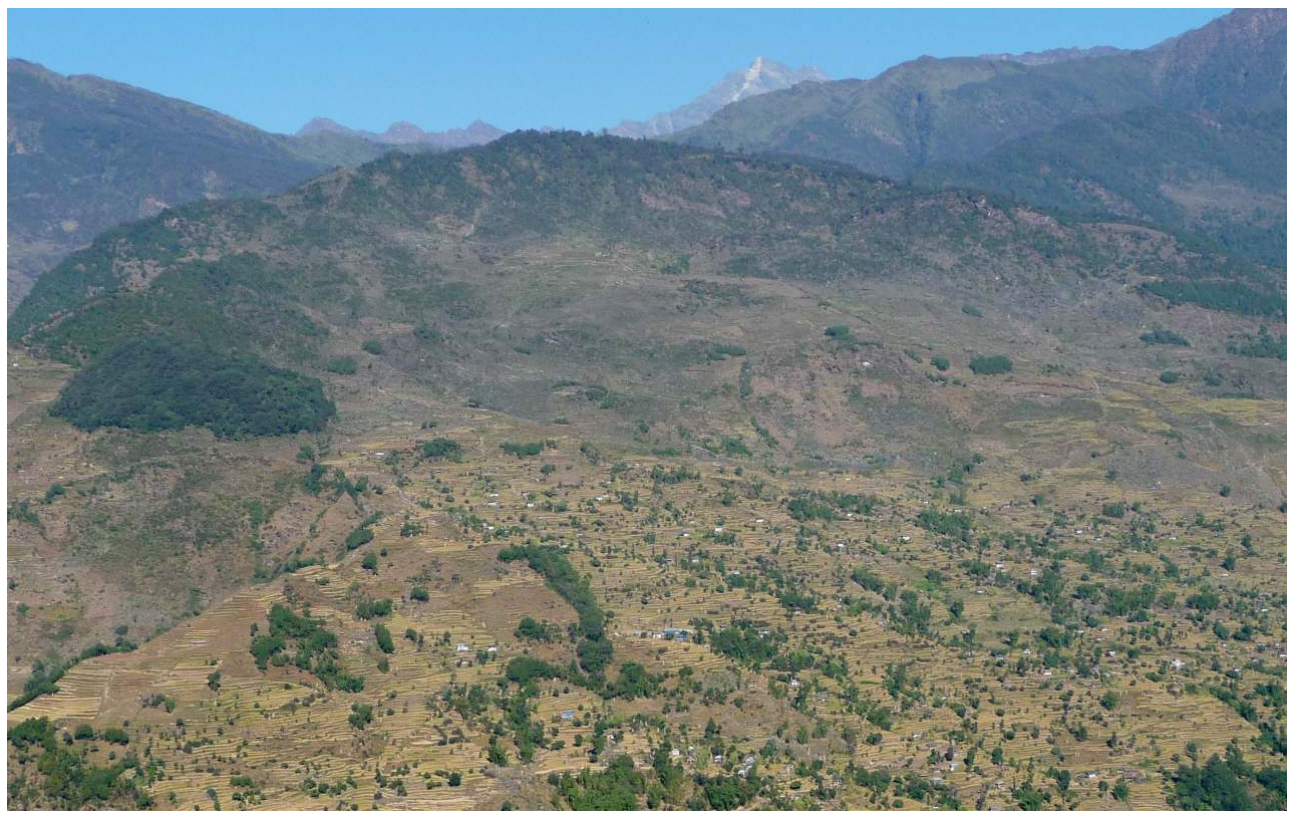

The first kulung public space? A queen-wood (rāni ban) above Phelmong village.

Parsuram, an elder descendant of the oldest and most important chief of the valley, who was well-acquainted with the past affairs of the area, shared another version of this story with me: "Before, in the queen's wood, there was no deity. This wood was taken for the benefit of the king, who made a document to protect it in the name of the queen. But if it is registered as guthi, the land no longer belongs to anyone; it is collective. That is why a deity was found in it. Then we recorded this forest as guthi land." Parsuram gives an instrumental interpretation of this establishment of the goddess shrine. By declaring the 
presence of a divinity, the area could be registered under the guthi land tenure and the wood could no longer be confiscated by the State. Even if guthi land is legally no longer the property of the donor, but that of the god or temple under whose name it has been registered, the original owner can continue to use it. By placing these forests under the protection of a goddess, their management reverts to those who honored the deity, namely the Kulung community. This is not an isolated case: M. C. Regmi mentions several examples of land registration as a religious gift for strategic reasons (1999:51-53; 1967). The importance of the land-struggle context in the emergence of the queen's wood is illustrated by the subsequent remarks made by this elder on a subject that is only apparently separate, since it concerns the context of the struggle for monopolization of lands:

Before, we cleared the forest and occupied the place. The Chetri, who were descendants of the king's officials and came from the south-west with their cattle, came to know about this. After having offered cheese as gift to the [Kulung] chiefs in order to be able to graze their cattle on our land, they cut the forest and then went to trial against us. That is why the Kulung wanted to drive them away. These trials concerning the forest began in the time of Khapsising [around 1850].

In a way this space, confiscated by the king, became through this retrieval a form of proto-public space: dedicated to an external power, it somehow transcended the community. The inscription of ritual areas under guthi tenure continued. A few decades later, in another queen's wood of the valley, another Devi appeared and that place also became guthi. Much later, after the agricultural-land registration of the nineties, DeviMahādev as well as $n \bar{a} g$ and tos shrines were also registered as guthi, which made the number of such spaces grow significantly. The term guthi also currently designates the group of participants in rituals performed at shrines located on guthi lands (as is customary among the Newar of Kathmandu valley). Thus, Bakhat Dhan said: "For divinities such as Āitabāre, we can perform the ritual ourselves. But those we 'believe' ( biśwās) a lot, they must be honored in groups (guthi). The whole village meets, and we perform guthi." Potentially accessible to all, anonymously, and not subject to private appropriation or state confiscation, these shrines form a kind of public space. And the appearance of public shrines and spaces went along with the growing presence of the State, and its increased control over space.

What can we conclude from this journey through the blossoming of permanent and collective shrines? Everything seems to start from a borrowing of rituals, according to an emic logic of seeking control over otherness: this consists in placating new misfortunes that accompany new populations, by appropriating their ritual techniques.

The appropriation of shrines-namely ritual devices including material representation of powers-which were added to the other already existing material ritual devices, had some important consequences. Up until then, bodies were the main material element through which powers manifested themselves in the form of misfortunes, and houses were the main setting for the performance of Kulung rituals. By giving powers an external material representation, the new arrangement "brought them out" of both bodies and houses. Moreover, some of the shrines have survived the performance of a ritual. This gave permanence to the powers. Since this emergence of shrines, powers and their rituals are no longer exclusively circumstantial and linked to a situation of misfortune. The new 
powers and the rituals relating to them were and still are autonomous both in space and in time.

The use of Nepali as ritual language and the origin of the powers in external communities embed the local community in a wider world. None of these new honored powers are specific to the Kulung; we find them in all the villages of the region or beyond. They transcend spatial and ethnic boundaries..$^{13}$ Through new misfortunes and new ritual technologies, the new rituals participate in the creation of a common inter-ethnic world.

As we have seen, the entire phenomenon of the emergence and development of shrines can be regarded as a Hinduization process. This process is not directly related to a highcast model; more than a Sanskritization process, one might call it a Hinduization "from below." It is motivated not by the desire to improve one's status but by the need to master unknown diseases. But being enshrined and therefore participating in a whole larger than the Kulung community-by speaking the (verbal and ritual) language of the dominant populations-can also be seen, in some cases, as a form of resistance; an appropriation of the dominant group's weapons in order to fight for the interests of one's own group. This is illustrated by the case of the emergence of the wood Devi we have described, which served the goal of taking the wood from the king and expelling the Chetri from the area.

But this is done at the risk of hierarchical inclusion. As they do with Bhimasen, the Kulung associate their Devī and Mahādev with larger sanctuaries. It is said that the Mahädev of Urbua is the little brother of Halesi, a very important religious site in eastern Nepal and the descendant (santān) of Paśupati, the famous temple of Kathmandu. These filiations are certainly prestigious, but in return they transform these Devī and Mahādev into local manifestations of more important temples' powers. While in Kulung rituals, the centers are the house fireplace and the tos shrine, in some Nepali rituals the spatial referents are urban (Dolakha), regional (Halesi) and national (Paśupati). Through these rituals the village has become a community that thinks of itself in relation to a center, as a part of a whole. By doing so, it subordinates itself to this whole.

Whether it is resistance or assimilation, the changes effected by rituals performed collectively on permanent shrines can be seen through the transformations that have affected the society. While older rituals are still practiced, the development of these novel rituals has created (and continues to sustain) new collectives, as shown in the comparison between tos and Devi-Mahādev rituals. This development marks the gradual erosion of community religiosity, founded on the consubstantial link to the land and territorial anchorage. This most ancient but still extant kind of religiosity and link is well-illustrated by the case of the tos ritual. Obtaining benefits during the tos is indeed based on the union of households in a joint community. Conversely, the privatization of the land seems to progressively lead to the empowerment of individuals and to the emancipation of rituals from previous kinds of community bonds. This is evident in the more recent development of prayer, pilgrimage and devotion-which are similar to Pan-Indian practices that can be grouped under the term bhakti-and which are based on personal, individual motivation.

Through the shift from shrines and rituals linked to a specific group and performed on a genealogical basis to rituals defined through a more spatial criterion, one can perceive the shift from the localized clan to the neighborhood, from the village as a community group to a more anonymous unit of settlement, "from the tribe to the peasantry" (Caplan 1991). To sum up, the Kulung villages and their inhabitants are thus slowly embedding themselves in the broader group that is the region, or even the nation, united 
by a form of popular Indo-Nepalese religion. This process is well-illustrated by the emergence and development of the shrines that we have examined in these pages.

\section{BIBLIOGRAPHY}

Allen, Nicholas. 1997. "Hinduization: The Experience of the Thulung Rai." Pp. 303-23 in Nationalism and Ethnicity in a Hindu Kingdom: The Politics of Culture in Contemporary Nepal, edited by D. N. Gellner, J. Pfaff-Czarnecka and J. Whelpon. Amsterdam: Harwood Academic Publisher.

Bazin, Jean. 1986. "Retour aux choses-dieux." Pp. 351-81 in Corps des dieux, edited by C. Malamoud and J.-P. Vernant. Paris: Gallimard.

Bickel, Balthasar and Martin Gaenszle. 1999. Himalayan Space: Cultural Horizons and Practices. Zürich: Völkerkundemuseum der Universität Zürich.

Cahiers du Centre Gustave Glotz 8. 1997. Section entitled "Pour un inventaire des lieux de culte de l'Italie antique." Pp 51-222.

Caplan, Lionel. 1970. Land and Social Change in East of Nepal: A Study of Hindu-tribal Relations. Berkeley: University of California Press.

Caplan, Lionel. 1991. "From Tribe to Peasant? The Limbus and the Nepalese State." The Journal of Peasant Studies 18(2):305-21.

Cartry, Durand and Renée Koch-Piettre. 2009. Architecturer l'invisible. Autels, ligatures, écriture. Turnhout: Brepols.

Egli, Werner. 2000. "Below the Surface of Private Property: Individual Rights, Common Property, and the Nepalese KipaŢ System in Historical Perspective." European Bulletin of Himalayan Research 18:5-19.

Forbes, Ann Armbrecht. 1999. "Mapping Power: Disputing Claims to Kipat Lands in Northeastern Nepal." American Ethnologist 26(1):114-38.

Gaenszle, Martin. 1993. "Interaction of an Oral Tradition: Changes in the Muddum of the Mewahang Rai of East Nepal." Pp. 117-25 in Nepal: Past and Present, edited by G. Toffin. New Delhi: Sterling Publishers.

Gaenszle, Martin. 2010. "Political Aspects of the Territorial Cult among the Mewahang Rai." Pp. 190-221 in Nature, Culture and Religion at the Crossroads of Asia, edited by M. Lecomte-Tilouine. New Delhi: Social Science Press.

Höfer, András and Bishnu Shrestha. 1973. "Ghost Exorcism among the Brahmans of Central Nepal.” Central Asiatic Journal 17(1):51-77.

Höfer, András. 1979. The Caste Hierarchy and the State in Nepal: A Study of the Muluki Ain of 1854. Innsbruck: Universitätsverlag Wagner.

Holmberg, David. 1989. Order in Paradox: Myth, Ritual, and Exchange among Nepal's Tamang. Delhi: Motilal Banarsidass Publishers.

Jones, Rex Lee. 1976. “Sanskritisation in Eastern Nepal.” Ethnology 15(1):63-75. 
Krauskopff, Gisèle. 1996. “Chefs, dieux du sol et cadastrage foncier au Népal.” Études rurales 143144:95-115.

Krauskopff, Gisèle and Marie Lecomte-Tilouine. 1996. Célébrer le pouvoir. Dasaĩ, une fête royale au Népal. Paris: CNRS Éditions.

Lussault, Michel. 2013. “Espace publique.” Pp. 360-64 in Dictionnaire de la géographie et de l'espace des sociétés, edited by M. Lussault and J. Lévy. Paris: Belin.

Macdougal, Charles. 1979. The Kulunge Rai: A Study in Kinship and Marriage Exchange. Kathmandu: Ratna Pustak Bhandar.

Padoux, André. 1990. L'Image divine. Culte et méditation dans l'hindouisme. Paris: CNRS.

Pignède, Bernard. 1966. Les Gurungs, une population himalayenne du Népal. Paris: Mouton.

Regmi, Mahesh Chandra. 1965. Land Tenure and Taxation in Nepal. Vol. III: The Jagir, Rakam, and Kipat Tenure Systems. Berkeley: University of California Press.

Regmi, Mahesh Chandra. 1967. Land Tenure and Taxation in Nepal. Vol. IV: Religious and Charitable Land Endowments: Guthi Tenure. Berkeley: University of California Press.

Regmi, Mahesh Chandra. [1977] 1999. Landownership in Nepal. Delhi: Adroit Publishers.

Revue de l'histoire des religions. 2010. 227(4), special issue entitled "Qu'est ce qu'un paysage religieux?"

Russel, Andrew. 2004. "Traditions in Transition: Sanskritization and Yakkhafication in East Nepal." History and Anthropology 15(3):251-61.

Sagant, Philippe. 1975. “Nationalité et état-nation. L'Exemple de l'intégration politique de Limbu du Népal.” Pluriel 2:3-20.

Sagant, Philippe. 1980. "Usuriers et chefs de clan. Ethnographie de la dette au Népal oriental." Pp. 227-77 in La dette, edited by C. Malamoud. Paris: École des Hautes Études en Sciences Sociales.

Sagant, Philippe. 1982. "Le Népal. L’Hinduisation des Limbu. - Tout Limbu était roi, autrefois." Pp. 209-39 in Les Royaumes de l'Himâlaya, edited by A. Macdonald. Paris: Imprimerie Nationale.

Scheid, John. 1997. “Comment identifier un lieu de culte?” Cahiers du Centre Gustave Glotz 8:51-59.

Schlemmer, Grégoire. 2004. "Vues d'Esprits. La Conception des esprits et ses implications chez les Kulung Rai." PhD dissertation, Department of Ethnology, Nanterre University.

Schlemmer, Grégoire. 2010a. "The Illness is the Other People: Cross-representations and Ritual Management of Alterity and Illness among the Kulung (Nepal)." Pp. 154-66 in Interethnic Dynamics in Asia: Ethnonyms, Considering the Other through Ethnonyms, Territories and Rituals, edited by C. Culas and F. Robinne. London and New York: Routledge.

Schlemmer, Grégoire. 2010b. "Le Rituel de l'Esprit Noir ou comment créer une présence pour manifester son absence.” Pp. 97-110 in Architecturer l'invisible. Autels, ligatures, écriture, edited by J.-L. Durand, M. Cartry and R. Koch-Piettre. Turnhout: Brepols.

Schlemmer, Grégoire. 2012. "Fils du territoire, alliés de la forêt. Expressions rituelles du rapport au territoire chez les Kulung Rai du Népal oriental." Moussons 19:33-50.

Schlemmer, Grégoire. 2016. "Voyageurs immobiles. La Géographie idéelle des Kulung Rai du Népal.” Pp. 227-47 in Territoires du religieux dans les mondes indiens. Parcourir, mettre en scène, franchir, edited by M. Claveyrolas and R. Delage. Paris: EHESS. 
Srinivas, M. Narasimhachar. 1967. Social Change in Modern India. Berkeley: University of California Press.

Srinivas, M. Narasimhachar. 1955. The Social System of a Mysore Village. Chicago: University of Chicago Press.

Steinmann, Brigitte. 1987. Les Tamang du Népal; usage et religion, religion de l'usage. Paris: CNRS.

Tarabout, Gilles. 2004. "Theology as History: Divine Images, Imagination, and Rituals in India." Pp. 56-84 in Images in Asian Religions: Texts and Contexts, edited by P. Granoff and K. Shinohara. Vancouver: UBC Press.

Turner, Ralph Lilley. [1931] 1980. A Comparative and Etymological Dictionary of the Nepali Language. New Delhi: Allied Publishers Private Limited.

Vauchez, André. 2000. Lieux sacrés, lieux de culte, sanctuaires. Approches terminologiques, méthodologiques, historiques et monographiques. Rome: École Française de Rome.

Vernant, Jean-Pierre. [1965] 2006. "Space and Political Organization in Ancient Greece.” Pp. 23559 in Myth and Thought among the Greeks, edited by J.-P. Vernant. New York: Zone Books.

Vernant, Jean-Pierre. [1983] 2006. "From the 'Presentification' of the Invisible to the Imitation of Appearance." Pp. 333-49 in Myth and Thought among the Greeks, edited by J.-P. Vernant. New York: Zone Books.

Vernant, Jean-Pierre. [1962] 2006. "The Figuration of the Invisible and the Psychological Category of the Double: The Kolossos." Pp. 321-32 in Myth and Thought among the Greeks, edited by J.-P. Vernant. New York: Zone Books.

Vincent, Jeanne-Françoise, Daniel Dory, and Raymond Verdier. 1995. La Construction religieuse du territoire. Paris: L'Harmattan.

\section{NOTES}

1. The Kulung form a group of some 30,000 people, whose language is part of the Tibeto-Burman linguistic family. Living in Nepal, they are the original inhabitants of the isolated valley of the Hongu at the foot of Everest massif. My data was mainly collected in Bung VDC, between 1996 and 2017. It is based on observations of rituals, informal conversations and interviews, mainly with men-both ritual specialists and "lay" people. A detailed description of the ethnographic context can be found in Schlemmer (2004). I transcribe Nepali words according to Turner's dictionary (1931) and Kulung words according to my own and imperfect system; in this paper, there is no agreement between foreign words and the singular/plural. I take the opportunity of this note to thank Serena Bindi, Vanina Bouté, Rémy Delage, Guillaume Rozenberg, Raphaël Voix and the anonymous reviewers for their comments.

2. The pertinence of this "wayside shrine" category is not patently obvious. To be so, it should be established on the basis of a set of specificities that set these shrines apart from other shrines. This would ideally involve a large comparative and typological study on religious sites and material ritual devices, such as that initiated by historians and archeologists of Greece and the Roman world (Cahiers du Centre Gustave Glotz 8 1997; Vauchez 2000; Revue de l'histoire des religions 2010), anthropologists of Africa (Vincent et al. 1995) or comparatively, by both (Cartry et al. 2009).

3. This consists in pronouncing the list of the stages separating the place where the ritual is performed to the place where the power is supposed to come from. Once it arrives, the ritual specialist verbally constructs a barrier to enclose it there, before coming back to the ritual place 
by listing the same stages backwards. This addition of imagined places further complicates the spatial dimension of rituals (Bickel and Gaenszle 1999; Schlemmer 2016).

4. For ethnographic details related to this ritual, see Schlemmer (2012) and Gaenszle (2010).

5. For a precise description of one of these pujā, see Schlemmer (2010b). This description can be usefully compared with the one given by Höfer (1973). On rituals without material representation -particularly among low castes-in Hinduism, and a reflection on such a notion of material representation, see Tarabout (2004).

6. More classical processes of Sanskritization also happened among the Kulung. During the kipat period, chiefs (dwāre, +/- 1850 to 1907, then jimmāwāl and tālukdār, 1907 to 1993) performed daśaĩ, the Nepalese equivalent of dasārā, the national "celebration of power" (Krauskopff and Leconte-Tilouine 1996). Some of these chiefs also started to summon Brahmans to perform prestigious rituals during the 1930s and this slowly became general practice. On Hinduization among the Rai and Kirant groups, to which the Kulung belong, see Jones (1976); Sagant (1982); Gaenszle (1993); Allen (1997); Russel (2004).

7. The isolation and the altitude $(1,500-2,500 \mathrm{~m})$ of the Kulung valley (which constrains the cultivation of irrigated rice) has limited the settlement of groups here, in contrast to most of the east of Nepal which, following its conquest and integration into the kingdom of Nepal at the end of the eighteenth century, has been vastly populated. The Kulung villages remain essentially mono-ethnic, but there are a number of hamlets populated by different groups. The groups are the low castes (mainly Kāmi Blacksmiths, present almost everywhere in Nepal, and the Damāi Dressmakers); the high castes (the Chetri or Kșatriya, and the Bāhun or Brahmans); the Newar, the original population of the Kathmandu valley; so called tribal groups which are more or less Hinduized (Magar, Gurung, Tamang); and the Sherpa, a group of Tibetan culture living in the heights.

8. By previous manifestation, I mean a disease or misfortune or a threat of such-as in the case of the tos ritual, which if not performed leads to a risk of famine. Ancestors are bound to their offspring by a contract that includes the feeding of the former by the latter, and this is expressed during funerals. Rituals addressed to the anscestors are therefore not free acts of worship motivated by personal desire.

9. This is despite the fact that they are onerous. While Mahādev only drinks milk, Devī requires raw goat's blood, despite the fact Kulung people cannot eat this meat, since in the mythical time a goat drank the blood of a sister's ancestor. Only children and unmarried people are allowed to eat goat.

10. In ritual incantations, mandir is used along with thān (“...in your thān-mandir...”). In its common usage, mandir is used to designate large temples outside the valley and, in some rare cases, it also refers to the shrines of Devī-Mahādev and to those of some nāg (those appearing-as Devī-Mahādev do-through a diviner's possession, a process I have not mentioned so as not to overburden the reader with detail). The notion of mandir seems to involve not the size of the building, but the importance of the power associated with it. Devī and Mahādev are among the few divinities that are sometimes called bhagawān (Sk. Bhagavat - revered) a word otherwise reserved for naming the divine as a rather impersonal but universal and transcendental reality (that is, the closest to the notion of "god"). Devī and Mahādev are also powers people address with "trust"/"faith" (biśwās).

11. For connections between Devī and territorial rituals such as tos among the Tamang and Gurung, see Pignède (1966:ch 13); Steinmann (1987:135-40); Holmberg (1989:85).

12. This process of kipat disintegration has been well studied. See in particular the works of Caplan (1970), Forbes (1999), Egli (2000) and Sagant (1975, 1980); for the Kulung, see Macdougal (1979).

13. The co-presence of various actors is one of the characteristics of the public space (Lussault 2013:360). This is mainly the case during melā, "a fair," "a festival" that takes place on certain full 
moon nights, in places marked by a self-manifested power-often Devī in the highlands such as lakes, passes, etc. (let us note that in this sole case, the resident place of the power and the place of worship is one and the same). Participation in these devotional cults (the only cults where I heard the notion of darśan mobilized), which are similar to pilgrimages, is voluntary and a melā attracts people of all castes from different villages, making them multi-ethnic rituals.

\section{ABSTRACTS}

What can the notion of "shrine," especially "wayside shrine," tell us about a society? A wayside shrine could be defined as an edifice including a material representation of powers, which is built in a public space and open to all. Such a definition leads us to focus on three main notions associated with it. First of all, that of material representation and its complex association with the presence of powers. Secondly, the notion of public space and how it emerges in relation with the state. And, finally, that of ritual unit and the question of what a ritual unit implies, besides the participation of its members in ritual activity. Describing the emergence of these types of shrines among the Kulung Rai, a so-called tribal society of the Nepalese Himalayas, will lead us to discuss some major changes that have occurred in this society over the last hundred and fifty years and that can be regarded as a Hinduization process coming "from below."

\section{INDEX}

Keywords: Nepal, shrine, altar, representation, Hinduization, public space, state control

\section{AUTHOR}

\section{GRÉGOIRE SCHLEMMER}

Research Institute for Development, URMIS. 